\title{
NOTE ON TRANSLITERATION, TRANSLATION, AND CITATION
}

In transliterating Cyrillic into Latin, I have followed the Library of Congress system, simplified form (as in SEEJ). Soft signs in proper names have been omitted. I have used a modified transliteration system, reflecting common usage, for the names of well-known authors. Thus, Gor'kii appears as Gorky, Gogol' as Gogol, Maiakovskii as Mayakovsky, Trotskii as Trotsky, Pil'niak as Pilniak, Il'f as Ilf, etc. When quoting secondary sources, I use their transliteration.

The references to Pilniak come from "O'kei: Amerikanskii roman," in Izbrannye proizvedeniia (Moscow: Khudozhestvennaia literatura, 1976). Unless otherwise indicated, translations from the Russian are mine, although citations to Korolenko's, Bogoraz's, Gorky's, Esenin's and Mayakovsky's autobiographical travelogues come from America Through Russian Eyes, 1874-1926, edited and translated by Olga Peters Hasty and Susan Fusso (New Haven, London: Yale University, 1988); the references to Ilf and Petrov come from Little Golden America, translated from the Russian by Charles Malamuth (New York: Arno Press, 1974). These sources are quoted in the text parenthetically by page number. 
